\title{
Using Fuzzy Set Approaches in a Raster GIS for Land Suitability Assessment at a Regional Scale: Case Study in Maros Region, Indonesia
}

\author{
Nurmiaty $^{1} \&$ Sumbangan Baja ${ }^{2,3}$ \\ ${ }^{1}$ Department of Estate Crops Cultivation, Pangkep State Polytechnic of Agriculture, South Sulawesi, Indonesia \\ ${ }^{2}$ Department of Soil Science, Hasanuddin University, Makassar, Indonesia \\ ${ }^{3}$ Center for Regional Development and Spatial Information (WITARIS), Hasanuddin University, Jl. Perintis \\ Kemerdekaan Km. 10, Makassar, 95245, Indonesia
}

Correspondence: Sumbangan Baja, Department of Soil Science, Hasanuddin University, Makassar, Indonesia. Tel (+Fax): 62-0411-587-076, E-mail: sbja02@yahoo.com.au

Received: March 1, 2014

doi:10.5539/mas.v8n3p115
Online Published: April 23, 2014

URL: http://dx.doi.org/10.5539/mas.v8n3p115

\begin{abstract}
Recently, spatial data on land resources have become more available, detailed, and sophisticated. Accordingly, it requires a method that could deal with those complex and detailed data in an effective way. A fuzzy set method with the semantic import model (SIM) was utilized within a raster GIS (geographic information systems) to analyze the area of Maros Regency on a reconnaissance scale basis. In this study, land attribute values were converted into continuous values (ranging from 0 to 1.0), according to the class limit determined based on field experiences, results of experiments, or fixed conventional standards. The evaluation criteria were based on land attributes which are divided into two main components: soil profile and topography. Each of land attributes within each component was valued from 0 (minimum) to 1.0 (maximum) according to the suitability of maize. Those values were represented as membership values, also ranging from 0 to 1.0. The result from land suitability analysis in Maros Regency for maize cultivation indicates that around $25 \%$ of land areas have a land suitability index (LSI) value of above 0.70 (suitable and very suitable), about $11 \%$ fall between 0.50 and 0.70 (moderately suitable), and $63 \%$ under 0.5 (not suitable). The main limiting factor for maize cultivation in this region is topography, especially slope gradient (s).
\end{abstract}

Keywords: fuzzy set, land suitability index, GIS, Maros Regency

\section{Introduction}

With the increasing availability of detailed spatial data on land resources, it requires a method that could deal with those data in an effective way, especially in assessing land quality for planning purposes. Basically, two basic types of land suitability evaluation are commonly recognized. The first is a categorical system (CS), and the second is based on continuous functions (CF) (Baja et al., 2001). As its name implies, the CS technique uses categorical classes to examine different levels of land properties and thus to represent the outputs generated. The system is also characterized by an a priori determination of 'land mapping units' that apply to all land attributes selected as evaluation criteria: these units will then become the basis for the output delineation of the overall analyses (Albaji et al., 2009; Al-Mashreki et al., 2011; Ashraf et al., 2011; Babalola et al., 2011; Chandio et al., 2011; Chinene et al., 2007; Jafarzadeh et al., 2008). The CF technique, on the other hand, takes into account the spatial continuity of land characteristics, and the outputs of the analysis are then presented as continuous grades (or indices) of land suitability. In the context of land resource assessment, a fuzzy set function (a continuous basis) is commonly used to undertake a CF technique (Baja et al., 2002; Burrough, 1989). Fuzzy set functions are also often used for other than land resources assessment areas, as done by Chen et al. (2010), Chiclana et al. (2007), Nardi and Nazori (2012), Mangaraj and Das (2008), Srivastava et al. (2013), Vucetic and Simonovic (2013), Wang and Chan (2013), and Zhang et al. (2013).

Maros Regency is currently developing a database of the region and runs several projects related to agricultural sector planning and development. The availability of data that has been built is thus important for application of more sophisticated and detailed methods to assist in more accurate land use planning until the stage of 
implementation. The main objective of this research is to assess land suitability for maize cultivation using a fuzzy set approach in a GIS. A raster based GIS was used to undertake every stage of spatial analysis in land suitability assessment.

\section{Method}

\subsection{Study Area}

The study area (Maros Regency) is located about $30 \mathrm{~km}$ north of Makassar City, the capital of South Sulawesi Province (Figure 1). It lies between latitudes $4^{\circ} 711^{\prime}$ and $5^{\circ} 2^{\prime} \mathrm{S}$, and stretches between longitudes $119^{\circ} 453^{\prime}$ to $119^{\circ} 977^{\prime} \mathrm{W}$. The area selected for this study includes all parts of Maros District covering a total area of 144,085 ha. Based on the land system map (RePPProT, 1988), the dominant soil type in study area are dystropepts, with an average distribution coverage is $76.236 \mathrm{ha}(52.9 \%)$, followed by tropaquepts and tropudults, with an average coverage is 38.640 ha $(26.8 \%)$ and 7.980 ha $(5.5 \%)$, respectively. Other soil types found in the area are rendolls, eutropepts, haplustults, and paleudults (see Nurmiaty \& Baja, 2013).

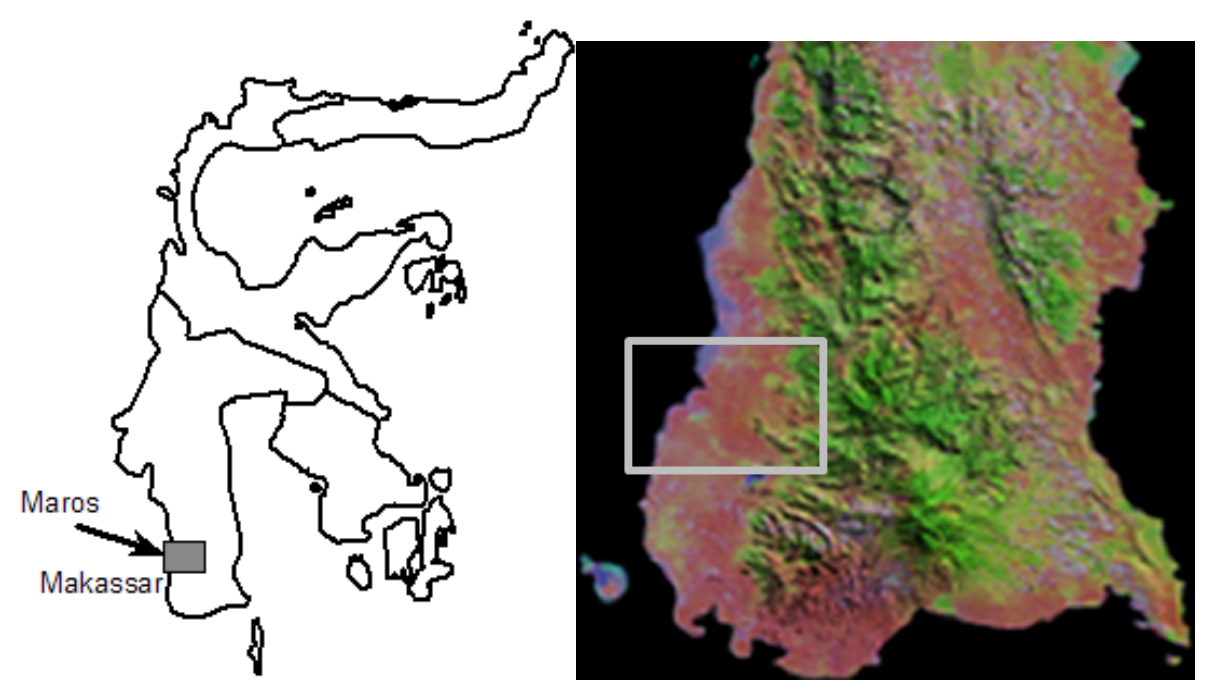

Figure 1. Location of study area (white box, right) in Sulawesi Island (left)

\subsection{Database and Preliminary Data Processing}

The main sources of database used in this study include: (i) digital topographic map; (ii) soil map and soil characteristics; (iii) climate data; and (iv) digital elevation model (DEM).

The primary reference for soil data layers is the results of soil survey undertaken by the local government of Maros Regency. Land mapping units (based on land system) were derived from a land system map to provide a basis for field survey (Figure 2). As many as 25 homogeneous mapping units were identified in the area of interest, and soil sampling was done in 25 locations. Soil and climate characteristics surveyed and analysed include the followings (see Table 1). The data on climate such as average temperature, rainfall, and number of dry months were obtained from local meteorological station of Maros. 


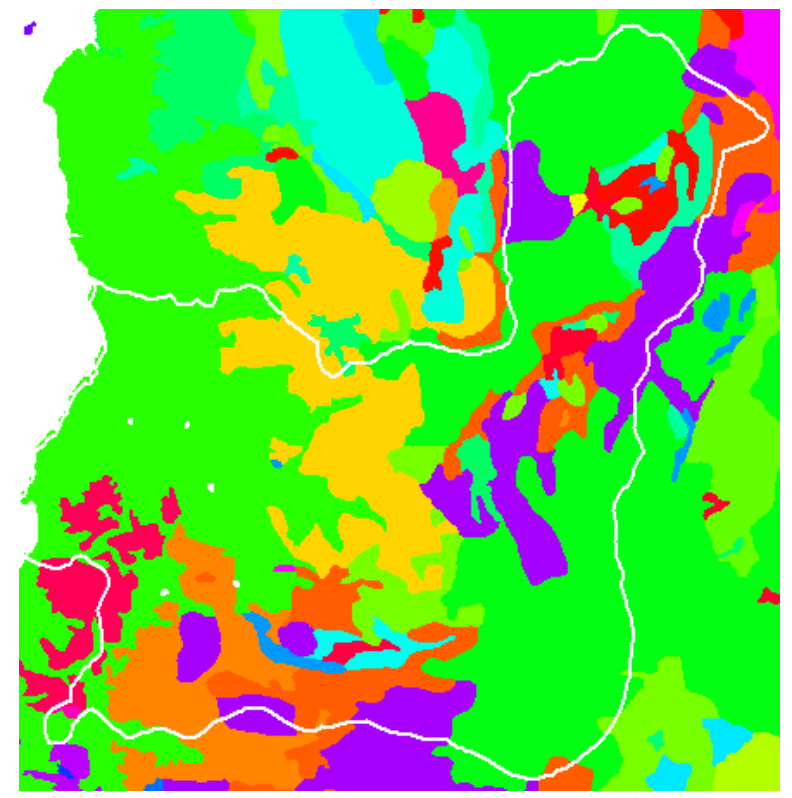

Figure 2. Land mapping unit (LMU) based on land system

Digital topographic maps of study area with a scale of 1:50,000 from the National Agency for Survey and Mapping were used as a reference for generating a DEM (Figure 3). The digital topographic maps were available in a vector GIS format, makes it easier to build database in a standard vector GIS, before converted to a raster format. All the data layers were stored using UTM (Universal Transverse Mercator) coordinate system. As the area of interest covers three sheets of topographic maps, then a process of joining all the elements of map layer was undertaken, before precisely defining the boundary of study area.
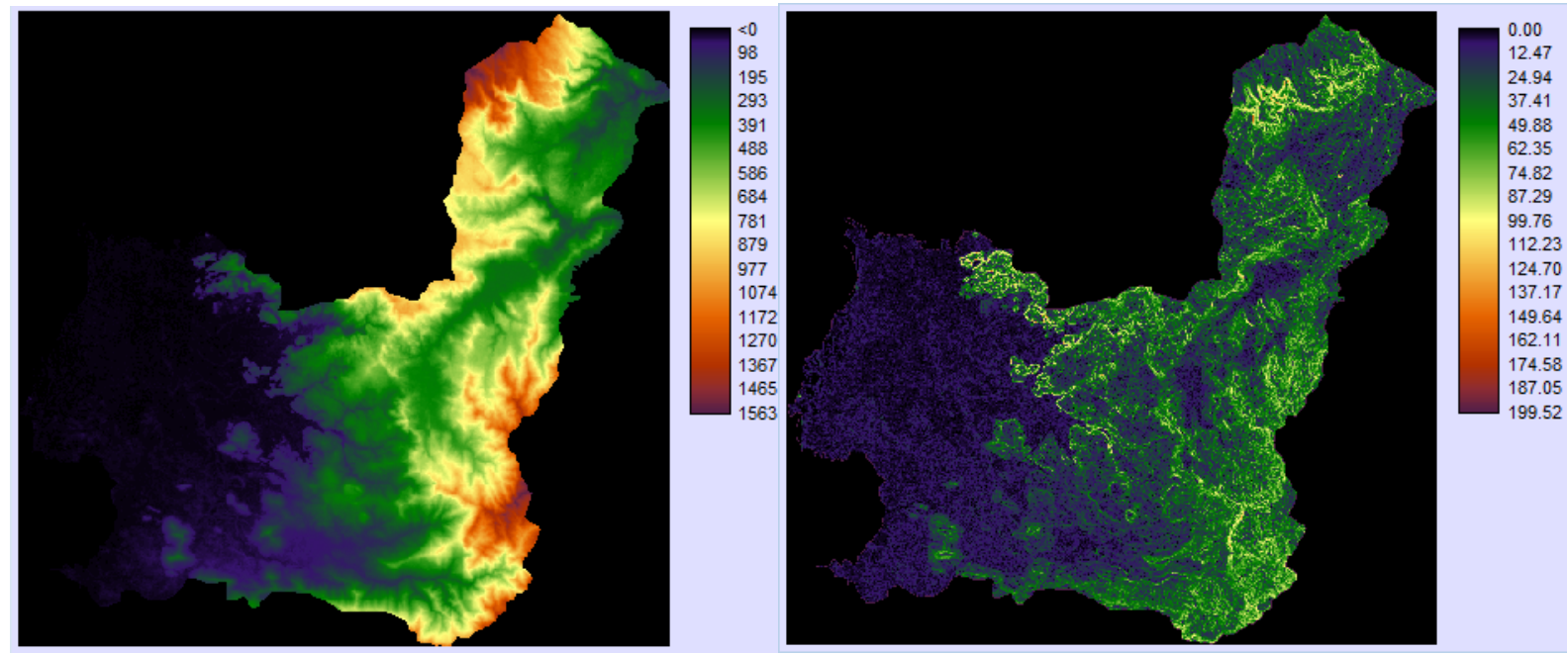

Figure 3. Digital Elevation Model (DEM) and derived slope map of study area 
Table 1. Land quality and land characteristics used in the analysis (base on Djaenuddin et al., 2003; FAO, 1976)

\begin{tabular}{ll}
\hline Land Qualities & Land Characteristics \\
\hline Temperature $(\mathrm{t})$ & Average temperature $\left({ }^{\circ} \mathrm{C}\right)$ \\
Water availability $(\mathrm{w})$ & Rainfall $(\mathrm{mm})$, number of dry months \\
Rooting condition $(\mathrm{r})$ & Texture, drainage, soil depth $(\mathrm{cm})$ \\
Nutrient retention (f) & Clay CEC $(\mathrm{cmol} / \mathrm{kg})$, base saturation $(\%), \mathrm{pH}(\mathrm{H} 2 \mathrm{O})$, organic C (\%) \\
Toxicity (x) & Salinity $(\mathrm{dS} / \mathrm{m})$ \\
Nutrient availability (n) & $\mathrm{N}, \mathrm{P}_{2} \mathrm{O}_{5}, \mathrm{~K}_{2} \mathrm{O}$ \\
Terrain $(\mathrm{s})$ & Slope $(\%)$, surface stoniness $(\%)$, surface outcrops $(\%)$ \\
\hline
\end{tabular}

\subsection{Fuzzy Set Method}

A fuzzy set method with the semantic import model (SIM) was utilized within a GIS to analyze the area of Maros Regency on a reconnaissance scale basis. In this study, land attribute values were converted into continuous values (ranging from 0 to 1.0) (Zadeh, 1965), according to the class limit determined based on field experiences, results of experiments, or fixed conventional standards (Baja, 2012; Galindo et al., 2005; Moreno, 2007; Sediyono et al., 2013; Sui, 1992). The evaluation criteria were based on land attributes which are divided into two main components: soil profile, and topography (Figure 4) (Baja, 2009; Baja et al., 2002). Figure 4 will include climate parameters if they have distinguished sub-region and are limiting for maize cultivation in the study area.

Each of land attributes within each component was valued from 0 (minimum) to 1.0 (maximum) according to the suitability of maize (see Keshavarzi et al., 2010, 2011; Kurtener et al., 2008; Mohammadrezaei et al., 2013; Reshmidevi et al., 2009; Sarmadian et al., 2010). Those values were represented as the membership value ranging from 0 to 1.0. Analytical procedure is conducted through the following steps: (i) selecting and designing evaluation criteria, (ii) standardizing the data set, (iii) determining the field/climate attribute values, (iv) choosing appropriate scoring functions and the parameters (Baja et al., 2001), (v) converting data format between software programs (raster to vector or vice versa). The analysis procedure is then continued to three main steps (see Baja et al., 2002, 2007).

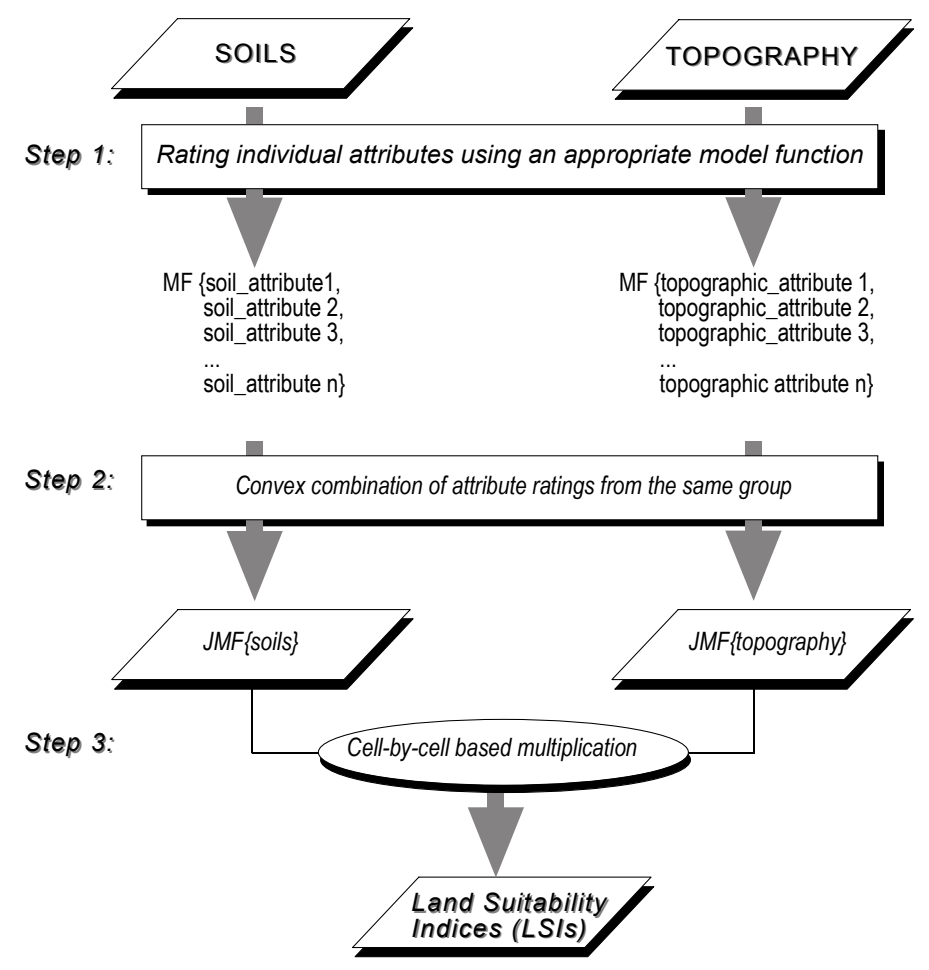

Figure 4. Schematic diagram of the procedure used in this study (source: Baja et al., 2002) 
Step 1, determination of the individual rank from the land attributes, using equations (Burrough, 1989):

$$
\mathrm{MF}(\mathrm{xi})=\left[1 /\left(1+\left\{\left(\mathrm{x}_{\mathrm{i}}-\mathrm{b}\right) / \mathrm{d}\right\}^{2}\right)\right] \text { if } 0<\mathrm{MF}\left(\mathrm{x}_{\mathrm{i}}\right)<1
$$

For optimum range (Model 2):

$$
\operatorname{MF}\left(\mathrm{x}_{\mathrm{i}}\right)=1 \text { if }\left(\mathrm{b}_{1}+\mathrm{d}_{1}\right)<\mathrm{x}_{\mathrm{i}}<\left(\mathrm{b}_{2}-\mathrm{d}_{2}\right)
$$

For asymmetric left (Model 3):

$$
\operatorname{MF}\left(\mathrm{x}_{\mathrm{i}}\right)=\left[1 /\left(1+\left\{\left(\mathrm{x}_{\mathrm{i}}-\mathrm{b}_{1}-\mathrm{d}_{1}\right) / \mathrm{d}_{1}\right\}^{2}\right)\right] \text { if } \mathrm{x}_{\mathrm{i}}<\left(\mathrm{b}_{1}+\mathrm{d}_{1}\right)
$$

For asymmetric right (Model 4):

$$
\operatorname{MF}\left(\mathrm{x}_{\mathrm{i}}\right)=\left[1 /\left(1+\left\{\left(\mathrm{x}_{\mathrm{i}}-\mathrm{b}_{2}+\mathrm{d}_{2}\right) / \mathrm{d}_{2}\right\}^{2}\right)\right] \text { if } \mathrm{x}_{\mathrm{i}}>\left(\mathrm{b}_{2}-\mathrm{d}_{2}\right)
$$

where $\operatorname{MF}\left(\mathrm{x}_{\mathrm{i}}\right)=$ the individual membership value for the $\mathrm{i}^{\text {th }}$ soil attribute $\mathrm{x}, \mathrm{d}=$ the range of transitional zone (that is, $x$ in $M F=0.5$ or otherwise mentioned as a crossover point, $C P$ ), $x_{i}=$ the $i^{\text {th }}$ soil attribute $(x)$ value, and $b$ $=$ the value of soil attribute $\mathrm{x}$ in the ideal point.

Step 2, derivation of the land attribute class rank, through the integration of the land attribute membership values using the following convex combination (Baja et al., 2002):

$$
\operatorname{JMF}(X)=\sum_{i=1}^{n} \lambda i M F(x i)
$$

where $0<J M F(X)<1 ; 0<M F x i<1 ; \lambda 1+\lambda 2+\lambda 3+\ldots+\lambda n=1$, and $0<\lambda i<1.0$. The JMF (X) symbol is the plural membership function from the entire variable that considered in the $\mathrm{X}$ class, $\lambda \mathrm{i}$ is the value factors for land attribute $\mathrm{x}$ which in $\mathrm{i}, \mathrm{MF}(\mathrm{xi})$ is the membership value for the $\mathrm{xi}$ land attribute, and $\mathrm{n}$ represent the number of land attributes considered.

Step 3, calculating an overall land suitability index (LSI), using the multiplication function which is based on the cell by cell in raster GIS, as follows:

$$
\operatorname{LSI}(\text { maize })=\operatorname{JMF}(S(p)) \times \operatorname{JMF}(T(p) \times \operatorname{JMF}(\mathrm{C}(p))
$$

where $\operatorname{LSIp}($ maize $)$ is $\operatorname{LSI}$ for maize at cell $\mathrm{p}, \operatorname{JMF}(\mathrm{S}(p)), \operatorname{JMF}(\mathrm{T}(p))$, and $\operatorname{JMF}(\mathrm{C}(p))$ are $\operatorname{JMF}$ value at cell $p$ for soil profile, topography, and climate, respectively. Use of multiplication function indicates that there is no compensation between land attribute. In other words, land area with an extreme limitation could not be compensated, by other excellent land characteristic, or vice versa (Baja et al., 2001, 2002). The multiplication function then generates a land suitability index (LSI) which is represented in the form of continuous value, ranging from 0 (not suitable) to 1.0 (very suitable) (Baja et al., 2002; Elaalem, 2010, 2012, 2013).

\section{Results and Discussion}

\subsection{Fuzzy Set Parameters}

The rating of soil attributes is established on the basis of the available soil mapping units (SMUs) which have 'crisp' boundaries, while that of topography is based on the DEM which has continuous values. Therefore, at this stage the unit for individual soil attributes is SMUs (see Figure 3), while for topography (slope) it is data cells in the DEM layer. (Nevertheless, it is necessary to point out that it is possible to use different mapping units for different soil attributes by using a kriging technique (Chaudhry et al., 2013; Gonzales et al., 2013; Taboada et al., 2013), which is better undertaken in detailed studies involving intensive soil sampling). In the present study, each land attribute is rated with values ranging from 0 (minimum) to 1.0 (maximum) according to its suitability for a nominated land use. Such values are represented as membership grades or membership function $(M F)$ values. The analysis indicates that the dominant MF values for internal soil attributes in the study area are between 0.80 and 0.90 .

Based on the suitability analysis using fuzzy set method, climate factor in the study area showed that all the data fulfilled the optimum criteria for the evaluation of land suitability of maize in the entire study area. Thus, the fuzzy parameter for climate value of the entire study area is 1.0 (maximum). Furthermore, the study area has a varied topography, ranging from flat to mountainous, with the gentle slope to very steep (Figure 3). The area is relatively flat and gentle slopes generally located in the western part of the study area, while mountainous area and steep terrain are found in the eastern part of the study area. Spatial distribution of land surface parameters using fuzzy method is shown in Figure 5. 


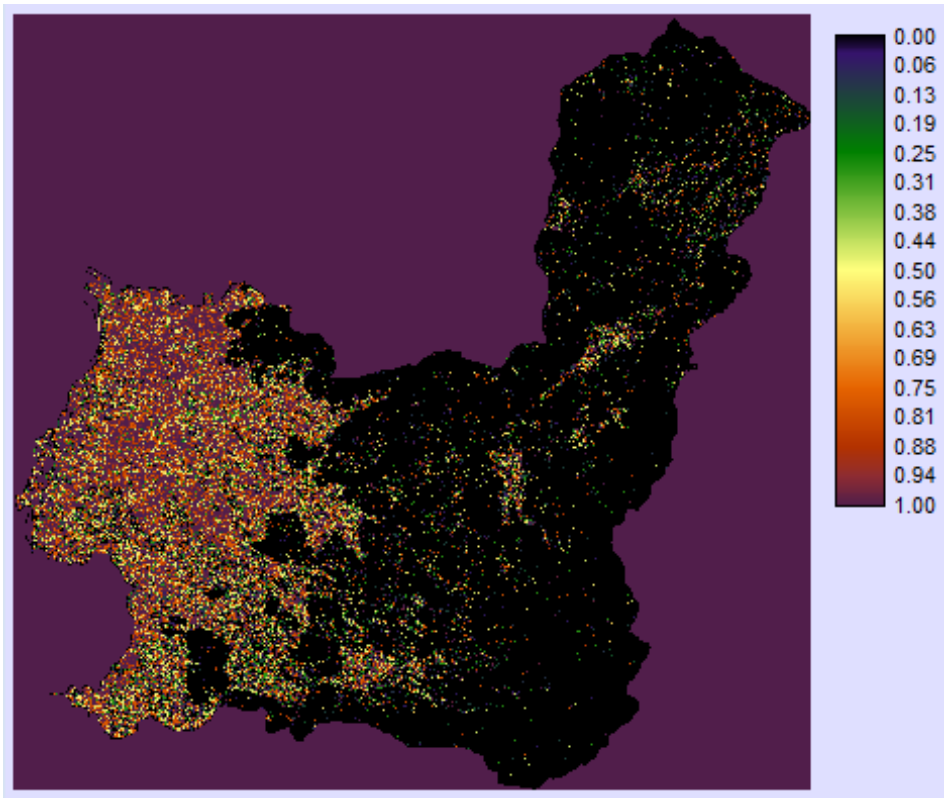

Figure 5. Distribution of MF value for slope gradient

\subsection{Land Suitability Index (LSI)}

Distribution of LSI derived from applying a fuzzy set method shown in Figure 6. The result from land suitability analysis in Maros Regency for maize cultivation indicates that around $25 \%$ of land areas have an LSI value of above 0.70 (suitable and very suitable), $\pm 11 \%$ fall between 0.50 and 0.70 (moderately suitable), and $\pm 63 \%$ under 0.5 (not suitable) (Figure 6). The main limiting factor for maize cultivation in this region is land surface, especially slope gradient (s).

The figures indicate that three-quarters of the study area is not suitable for the development of maize, and predominantly caused by slope gradient factors, although it was found that soil attributes are in a good condition. Furthermore, about one-third of the study area is available (as appropriate) for the development of maize, by assuming that the decision makers will give the highest priority to areas above LSI values of more than 0,50 (marginally, moderately, and suitable) (see also classification in Table 2).

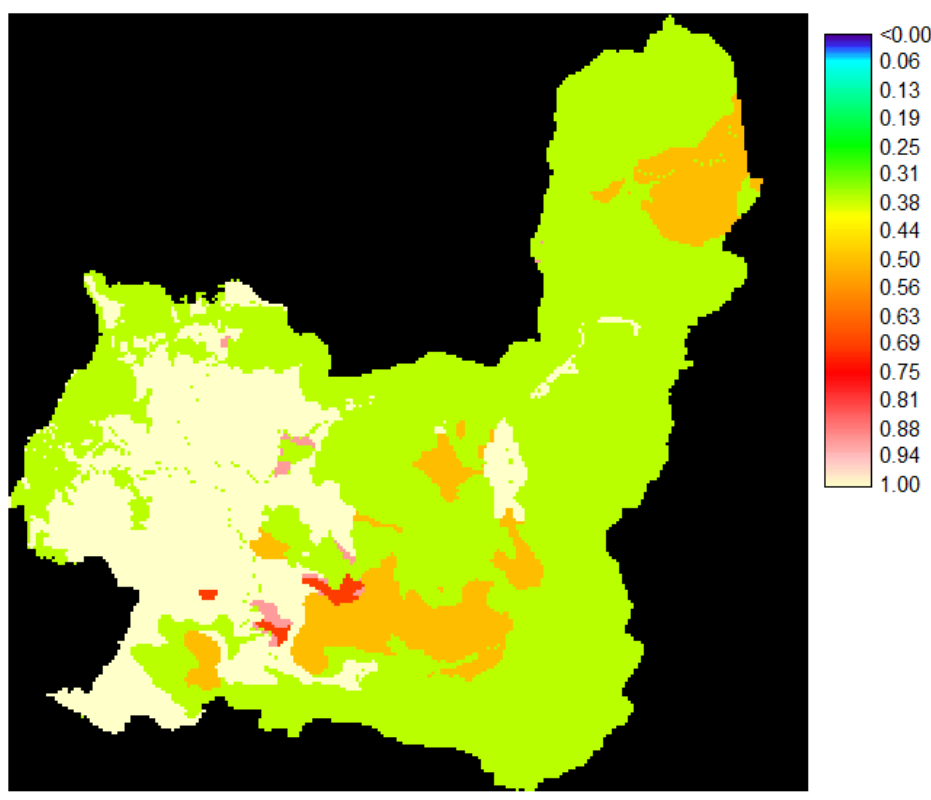

Figure 6. Distribution of LSI derived from applying a fuzzy set method 
Figure 7 presents LSI distribution after reclassification into five classes. Percentage of LSI coverage is presented in Table 2. Area with the highest coverage is class 1 (not suitable for corn planting) accounted for $64.21 \%$ and followed by class 5 (very suitable for maize) accounted for $24.17 \%$. There is a substantial proportion of area unsuitable for maize due to a sulphuric characteristic and became limiting for the development of maize cultivation.

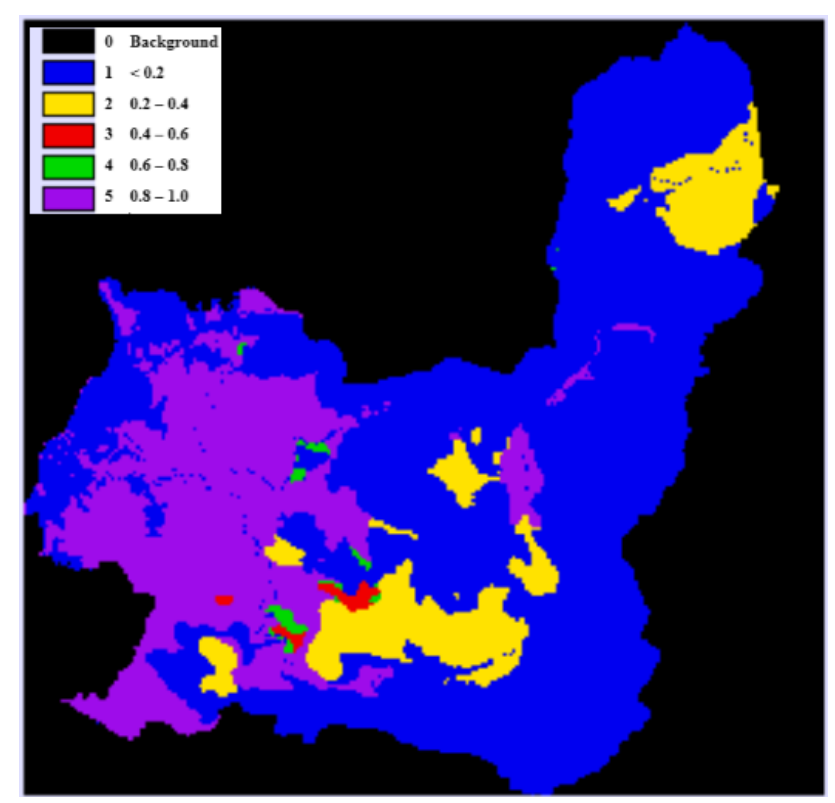

Figure 7. Distribution of LSI after reclassing according to classes

Table 2. Land suitability for maize in the study area

\begin{tabular}{lclrc}
\hline Class & \multicolumn{1}{l}{ LSI } & Land suitability category & Area (ha) & Percent from total area (\%) \\
\hline 1 & $<0.2$ & Permanently not suitable & $90,568.79$ & 64.21 \\
2 & $0.2-0.4$ & Currently not suitable & $14,966.75$ & 10.61 \\
3 & $0.4-06$ & Marginally suitable & 662.63 & 0.47 \\
4 & $0.6-0.8$ & Moderately suitable & 749.06 & 0.53 \\
5 & $0.8-1.0$ & Suitable & $34,096.54$ & 24.17 \\
\hline Total & & & $141,043.78$ & 100 \\
\hline
\end{tabular}

\subsection{Ground Observation}

The purpose of ground observation is to see the difference in quality of land in different land index. As shown in Figure $8 \mathrm{a}$ with quality land suitable for corn (LSI $0.8-1.0$ ), $8 \mathrm{~b}$ moderately suitable land quality (LSI 0.6-0.8), $8 \mathrm{c}$ marginally suitable (LSI 0.4-06), 8d currently not suitable (LSI 0.2-0.4), and 8e are permanently not suitable (LSI $<0.2$ ). Figure $8 \mathrm{~d}$ is limited by nutrient deficiency factor and slope, being in the figure $8 \mathrm{e}$ constrained by the slope, surface rock and soil depth factors. 

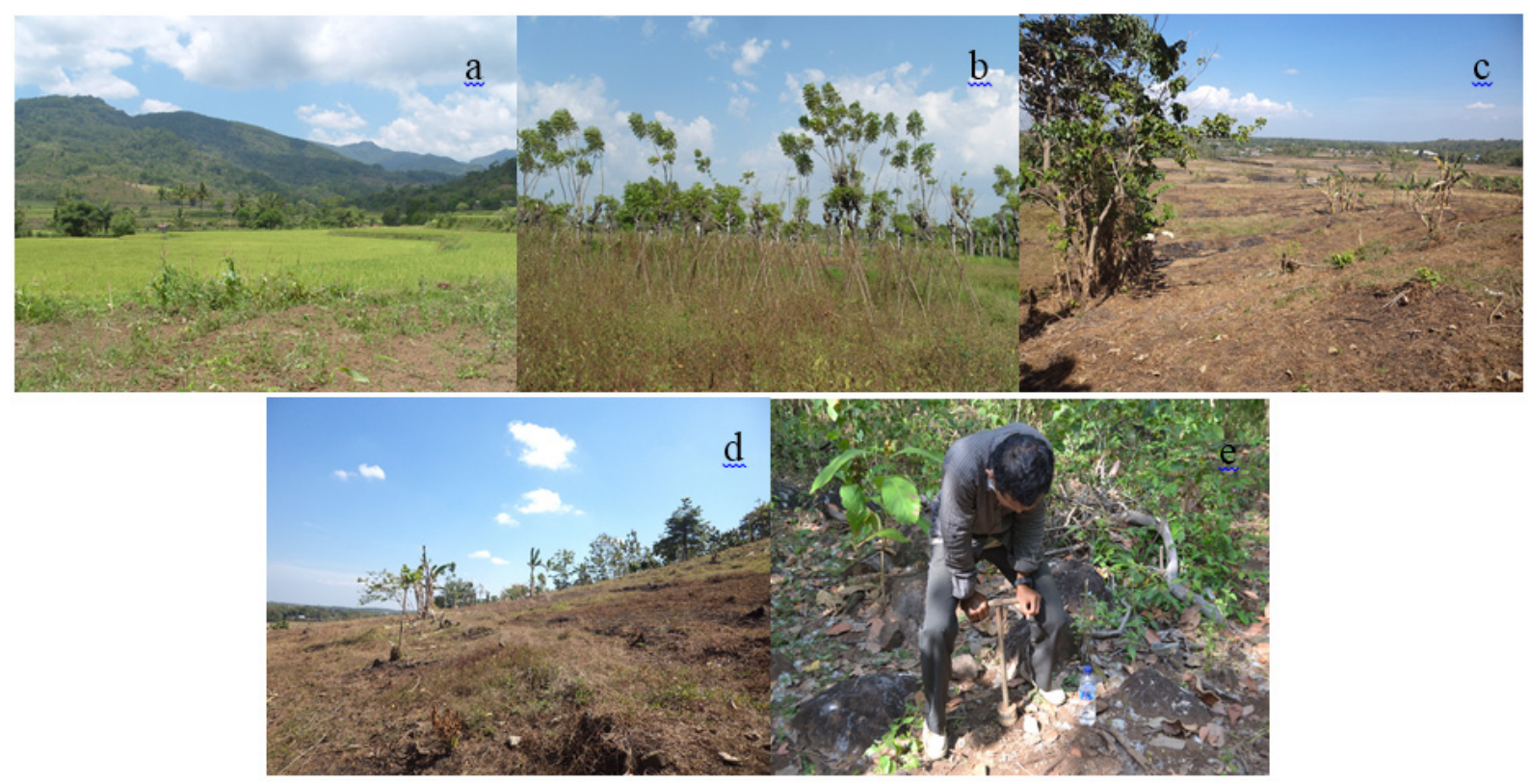

Figure 8. Visualisation of land quality in accordance with suitability for corn: a. suitable (LSI 0.8-1.0), b. moderately suitable (LSI 0.6-0.8), c. marginally suitable (LSI 0.4-06), d. currently not suitable (LSI 0.2-0.4), e. permanently not suitable (LSI $<0.2)$

The main limiting factor to agricultural development in the study area is slope gradient. In this area, steep slope is quite dominant, especially in the eastern and northeastern parts. Land area with slopes of more than $17 \%$ and is not suitable for agricultural development, is found almost half of the total study region (see Figure 9). The rest is areas having a slope of less than $17 \%$, occupying areas currently used for agricultural land, including rice fields, plantations, and dryland agriculture. The area suitable for agriculture development is predominantly found in the western part of the study area (see Figure 3). Other factors that are limiting in the area of interest are soil depth and surface stoniness. Both factors seem to correlate and are generally found in areas that lie within a steep slope (see Figure 8e).

This analysis also confirms that LSI values tend to correspond with the limiting factors mentioned above, where LSI is lower in areas that have heavy limitations (generally in the eastern and northeastern) and higher in areas that have a light limiting condition (in western section). Based on previous study (Nurmiaty \& Baja, 2013), most of maize farming areas in Maros regions are found in areas with slope $>17 \%$ (Tompobulu, Camba, Moncongloe, Mandai and Mallawa subdistricts) while areas with slope $<17 \%$ is generally used for urban areas and paddy fields (Maros Baru, Turikale, Lau, Bantimurung and Simbang subdistricts). Some proportion of land areas for maize is also found in coastal zones (Bontoa Subdistrict). Due to extensive farming of maize in a relatively steep land, farming communities in this area have recently received a negative impact on the environment such as flash floods, droughts, and landslides, and such natural phenomena have never been occurred before in Maros (Nurmiaty et al., 2014).

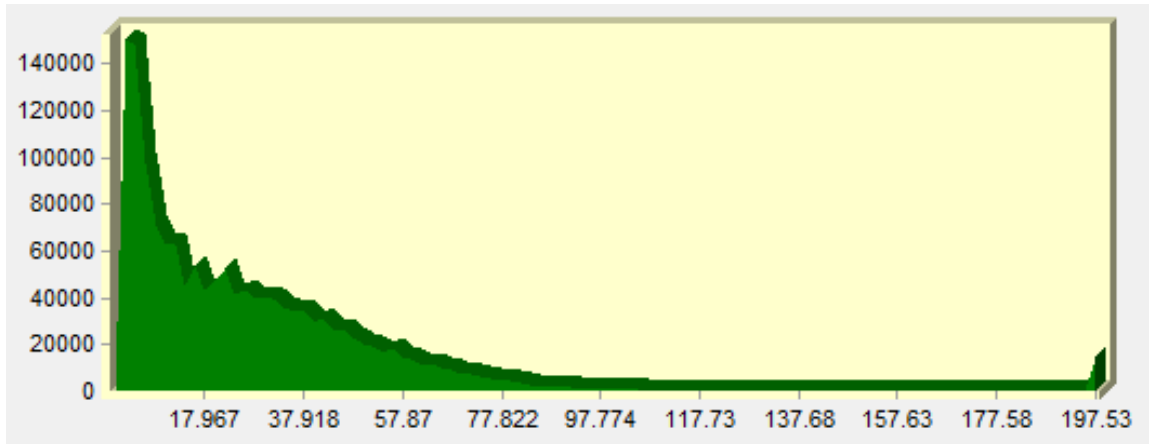

Note: X-axis: slope (degree), Y-ordinat: number of pixels (1 pixel= 30 × 30 meters)

Figure 9. Spatial distribution of slope in the study area 


\section{Conclusion}

This study has performed the use of fuzzy set in the assessing land suitability for maize cultivation in Maros region. The evaluation criteria were based on land attributes which are divided into two main components: soil profile and topography. Each of field attributes within each component was valued from 0 (minimum) to 1.0 (maximum) according to the suitability of maize. Those values were represented as the membership values, also ranging from 0 to 1.0 . The results indicate that around $25 \%$ of land areas have an LSI value of above 0.70 (suitable and very suitable), $\pm 11 \%$ fall between 0.50 and 0.70 (moderately suitable), and $\pm 63 \%$ under 0.5 (not suitable). Three-quarters of the study area is not suitable for the development of maize, and predominantly caused by slope gradient factors, and the rest one-third of the study area is suitable for the development of maize, with LSI values of more than 0,50 (moderately, suitable, and very suitable).

\section{Acknowledgements}

The authors are deeply thankful to the DP2M DIKTI (through the HIBAH KOMPETENSI research grand), Maros Regency government (Bappeda Maros), and The Center for Regional Development and Spatial Information (WITARIS), Hasanuddin University, for providing data, fund, and other supporting facilities in this study.

\section{References}

Albaji, M., Naseri, A. A., Papan, P., \& Nasab, S. B. (2009). Qualitative evaluation of land suitability for principal crops in The West Shoush Plain, Southwest Iran. Bulgarian Journal of Agricultural Science, 15(2), 135-145.

Al-Mashreki, M. H., Akhir, M., Bin, J., Rahim, S. A., Desa, K. M., Lihan, T., \& Haider, A. R. (2011). Land suitability evaluation for sorghum crop in the Ibb Governorate, Republic of Yemen using remote sensing and GIS techniques. Australian Journal of Basic and Applied Sciences, 5(3), 359-368.

Ashraf, S. H., Manoukyan, R., \& Ayoubi, S. H. (2011). Land suitability evaluation in Damghan Plain for Barley, using compare and conformity methods (Northeast-Iran). Pakistan Journal of Biological Sciences, 14, 123-127. http://dx.doi.org/10.3923/pjbs.2011.123.127

Babalola, T. S., Oso, T., Fasina, A. S., \& Godonu, K. (2011). Land evaluation studies of two wetland soils in Nigeria. International Research Journal of Agricultural Science and Soil Science, 1(6), 193-204.

Baja, S. (2009). Land use choice and land resource assessment in agriculture. CAB Reviews: Perspectives in Agriculture, Veterinary Science, Nutrition and Natural Resources, 4(15), 1-9. http://dx.doi.org/10.1079/PAVSNNR20094015

Baja, S. (2012). Perencanaan Tata Guna Lahan dalam Pengembangan Wilayah: Pendekatan Spasial dan Aplikasinya. Penerbit Andi, Yogyakarta.

Baja, S., Chapman, D. M., \& Dragovich, D. (2001). A conceptual model for assessing agricultural land suitability at a catchment level using a continuous approach in GIS. Proceedings of the Geospatial Information and Agriculture Conference (pp. 828-841). Sydney NSW Agriculture, Sydney.

Baja, S., Chapman, D. M., \& Dragovich, D. (2002). A conceptual model for defining and assessing land management units using a fuzzy modelling approach in GIS environment. Environmental Management, 29, 647-661. http://dx.doi.org/10.1007/s00267-001-0053-8

Baja, S., Dragovich, D., \& Chapman, D. (2007). Spatial based compromise programming for multiple criteria decision making modeling in land use planning. Environmental Modelling and Assessment, 12, 171-184. http://dx.doi.org/10.1007/s10666-006-9059-1

Burrough, P. A. (1989). Fuzzy mathematical methods for soil survey and land evaluation. Journal of Soil Science, 40(3), 477-492. http://dx.doi.org/10.1111/j.1365-2389.1989.tb01290.x

Chandio, I. A., Matori, A. N., Lawal, D. U., \& Sabri, S. (2011). GIS-based land suitability analysis using AHP for public parks planning in Larkana City. Modern Applied Science, 5(4), 177-189. http://dx.doi.org/10.5539/mas.v5n4p177

Chaudhry, A., Khan, A., Kim, J. Y., \& Niu, Q. Q. (2013). Intelligent Image Restoration Approach: Using Neural Networks to Eradicate Dilemma in Punctual Kriging. Life Science Journal, 10(1), 1631-1641.

Chen, Y., Khan, S., \& Paydar, Z. (2010). To retire or expand? A fuzzy GIS-based spatial multi-criteria evaluation framework for irrigated agriculture. Irrigation and Drainage, 59, 174-188. 
Chiclana, F., Herrera-Viedma, E., Herrera, F., \& Alonso, S. (2007). Some induced ordered weighted averaging operators and their use for solving group decision-making problems based on fuzzy preference relations. European Journal of Operational Research, 182, 383-399. http://dx.doi.org/10.1016/j.ejor.2006.08.032

Chinene, V. R. N. (2007). Land evaluation using the FAO framework: an example from Zambia. Soil Use and Management, 8(3), 130-138. http://dx.doi.org/10.1111/j.1475-2743.1992.tb00908.x

Djaenuddin, D., Marwan, H., Subagjo, H., \& dan Hidayat, A. (2003). Petunjuk Teknis Evaluasi Lahan untuk Komoditas Pertanian. Versi 3. Balai Penelitian Tanah, Puslitbang Tanah dan Agroklimat, Bogor.

Elaalem, M. (2012). Land suitability evaluation for sorghum based on boolean and fuzzy-Multi-Criteria Decision Analysis Methods. International Journal of Environmental Science and Development, 3(4), 357-361. http://dx.doi.org/10.7763/IJESD.2012.V3.247

Elaalem, M. (2013). A comparison of parametric and fuzzy multi-criteria methods for evaluating land suitability for olive in Jeffara Plain of Libya. APCBEE Procedia, 5, 405-409. http://dx.doi.org/10.1016/j.apcbee.2013.05.070

Elaalem, M., Comber, A., \& Fisher, P. (2010). Land evaluation techniques comparing fuzzy AHP with TOPSIS methods. Proceeding of the $13^{\text {th }}$ AGILE International Conference on Geographic Information Science (pp. 1-8). Guimarães, Portugal.

Food and Agriculture Organization (FAO). (1976). A Framework for Land Evaluation. FAO Soil Bulletin 32. FAO and Agriculture Organization of the United Nation, Rome.

Galindo, J., Urrutia, A., \& Piattini, M. (2005). Fuzzy Databases: Modelling, Design, Implementation. Idea Group Publishing, London the United Kingdom and the United States of America. http://dx.doi.org/10.4018/978-1-59140-324-1

Gonzales, A. S., Galan, C. O., Castro, J. T., Perez, E. G., \& Fernandez, C. S. (2013). Grade control in a quartz deposit using universal fuzzy kriging. Dyna, 80(178), 61-69.

Jafarzadeh, A. A., Alamdari, P., Neyshabouri, M. R., \& Saedi, S. (2008). Land suitability evaluation of bilverdy research station for wheat, barley, alfalfa, maize and safflower. Soil and Water Res., 3(Special Issue), 581-588.

Keshavarzi, A., Sarmadian, F., Heidari, A., \& Omid, M. (2010). Land suitability evaluation using fuzzy continuous calssification (a case study: Ziaran region). Modern Applied Science, 4(7), 72-81.

Keshavarzi, A., Sarmadian, F., Labbafi, R., \& Vandechali, M. R. (2011). Modeling of soil cation exchange capacity based on fuzzy table look-up scheme and artificial neural network approach. Modern Applied Science, 5(1), 153-164.

Kurtener, D., Torbert, H. A., \& Krueger, E. (2008). Evaluation of agricultural land suitability: application of fuzzy indicators. In Computational Science and Its Applications-ICCSA 2008 (pp. 475-490). Springer Berlin Heidelberg. http://dx.doi.org/10.1007/978-3-540-69839-5_35

Mangaraj, B. K., \& Das, D. K. (2008). Interactive fuzzy multi-objective programming in land re-organisational planning for sustainable rural development. World Academy of Science, Engineering and Technology, 23, 104-113.

Maros, B. P. S. (2012). Kabupaten Maros Dalam Angka. Kantor Badan Statistik Kabupaten Maros.

Mohammadrezaei, N., Pazira, E., Sokoti, R., \& Ahmadi, A. (2013). Comparing the performance of fuzzy ahp and parametric method toevaluate of land suitability of wheat production in the Southern Plain of Urmia. International Journal of Agronomy and Plant Production, 4(12), 3438-3443.

Moreno, J. F. S. (2007). Applicability of knowledge-based and fuzzy theory-oriented approaches to land suitability for upland rice and rubber, as compared to the farmers' perception, a case study of Lao PDR. M.S. Thesis, Consortium partners: University of Southampton (UK), Lund University (Sweden), University of Warsaw (Poland), International Institute for Geo-Information Science and Earth Observation (ITC) (The Netherlands).

Nardi, \& Nazori A. Z. (2012). Otomasi klasifikasi awan citra satelit MTSAT dengan pendekatan fuzzy logic. Jurnal Telematika Mkom, 4(1), 104-117.

Nurmiaty, \& Baja, S. (2013). Spatial Based Assessment of Land Suitability and Availability for Maize (Zea mays L.) Development in Maros Region, South Sulawesi, Indonesia. Open Journal of Soil Science, 3, 244-251. 
http://dx.doi.org/10.4236/ojss.2013.35029

Nurmiaty, Baja, S., \& Arif, S. (2014). GIS-Based Modelling of Land Use Dynamics Using Cellular Automata and Markov Chain. Journal of Environment and Earth Science, 4(4), 61-66.

RePPProT. (1988). The Land Resources of Indonesia: A National Overview Main Report. United Kingdom-ODA NRI, Ditjen Pankim, Department of Transmigration, Jakarta.

Reshmidevi, T. V., Eldho, T. I., \& Jana, R. (2009). A GIS-integrated fuzzy rule-based inference system for land suitability evaluation in agricultural watersheds. J. Agricultural Systems, 101, 101-109. http://dx.doi.org/10.1016/j.agsy.2009.04.001

Sarmadian, F., Keshavarzi, A., Rajabpour, B., \& Askari, S. (2010). Application of MCDM method in fuzzy modeling of land suitability evaluation. Proceeding of the $19^{\text {th }}$ world congress of soil science, soil solutions for a changing world (pp. 25-28). Brisbane, Australia, August 1- 6.

Sediyono, E., Setiawan, A., \& Kaparang, D. R. (2013). Fuzzy simple additive weighting algorithm to determine land suitability for crop in Minahasa Tenggara. International Journal of Computer Applications, 84(7), 26-29. http://dx.doi.org/10.5120/14591-2829

Srivastava, P., Burande, A., \& Sharma, N. (2013). Fuzzy environmental model for evaluating water quality of Sangam Zone during Maha Kumbh. Applied Computational Intelligence and Soft Computing, 2013, Article ID 265924. http://dx.doi.org/10.1155/2013/265924

Sui, D. Z. (1992). A fuzzy GIS modeling approach for urban land evaluation. J. Computer, Environment and Urban Systems, 16, 101-115. http://dx.doi.org/10.1016/0198-9715(92)90022-J

Taboada, J., Saavedra, Á., Iglesias, C., \& Giráldez, E. (2013). Estimating quartz reserves using compositional kriging. Abstract and Applied Analysis, 2013, Article ID 716593. http://dx.doi.org/10.1155/2013/716593

Vucetic, V., \& Simonovic, S. P. (2013). Evaluation and application of Fuzzy Differential Evolution approach for benchmark optimization and reservoir operation problems. Journal of Hydroinformatics, 15(4).

Wang, X., \& Chan, H. K. (2013). An integrated fuzzy approach for evaluating remanufacturing alternatives of a product design. Journal of Remanufacturing, 3, 10. http://dx.doi.org/10.1186/2210-4690-3-10

Zadeh, L. A. (1965). Fuzzy sets. J. Information and Control, 8, 338-353. http://dx.doi.org/10.1016/S0019-9958(65)90241-X

Zhang, Q., Yang, X., Zhang, Y., \& Zhong, M. (2013). Risk assessment of groundwater contamination: a multilevel fuzzy comprehensive evaluation approach based on DRASTIC model. The Scientific World Journal, 2013, Article ID 610390. http://dx.doi.org/10.1155/2013/610390

\section{Copyrights}

Copyright for this article is retained by the author(s), with first publication rights granted to the journal.

This is an open-access article distributed under the terms and conditions of the Creative Commons Attribution license (http://creativecommons.org/licenses/by/3.0/). 